\title{
The MHC-II transactivator CIITA, a viral restriction factor inhibiting the replication of Human T-Cell Lymphotropic Virus Type 1
}

\author{
Giovanna Tosi ${ }^{*}$, Greta Forlani ${ }^{1}$, Vibeke Andresen ${ }^{2}$, Marco Turci ${ }^{3}$, Umberto Bertazzoni $^{3}$, Genoveffa Franchini ${ }^{4}$, \\ Roberto S Accolla ${ }^{1}$
}

From 15th International Conference on Human Retroviruses: HTLV and Related Viruses Leuven and Gembloux, Belgium. 5-8 June 2011

Human T-cell Lymphotropic Virus type-1 (HTLV-1) is the causative agent of an aggressive malignancy of CD4 $+\mathrm{T}$ lymphocytes. It is believed that the viral transactivator Tax-1 is a major player in T-cell transformation. Thus, targeting Tax-1 protein is regarded as a possible strategy to arrest viral replication and ultimately to counteract neoplastic transformation.

Here, we demonstrated that CIITA, the master regulator of MHC class II gene transcription, inhibits HTLV-1 replication by blocking the transactivating function of Tax-1. Co-immunoprecipitation experiments have shown that CIITA and Tax-1 physically interact in vivo and that the first 108 amino acids of Tax-1 were necessary for this binding. Two adjacent regions (1-252 and 253-410) of CIITA bound independently to Tax-1, but only region 1-252 mediated Tax-1 inhibition, in agreement with the fact that CIITA residues from positions 64-124 were required to block Tax-1 transactivation. CIITA inhibitory action on Tax-1 function correlated with the nuclear localization of CIITA and was independent of the transcription factor NF-YB, previously involved in CIITA-mediated inhibition of Tax-2 of HTLV-2, a virus with still elusive pathogenic action. Furthermore, CIITA severely impaired the physical and functional interaction of Tax-1 with the cellular co-activator PCAF, which is required for the optimal activation of HTLV-1 promoter. Accordingly, the over-expression of PCAF restored Tax-1-dependent transactivation of the viral LTR promoter inhibited by CIITA.

\footnotetext{
* Correspondence: giovanna.tosi@yahoo.com

'Department of Experimental Medicine, University of Insubria, Varese, 21100, Italy

Full list of author information is available at the end of the article
}

These findings strongly support our original observation that CIITA, beside increasing the antigen-presenting function for pathogen antigens, acts as an endogenous restriction factor against human retroviruses by blocking virus replication and spreading.

\section{Author details}

'Department of Experimental Medicine, University of Insubria, Varese, 21100, Italy. ${ }^{2}$ Institute of Medicine, Hematology section, University of Bergen, Bergen, Norway. ${ }^{3}$ Department of Life and Reproduction Sciences, Section of Biology and Genetics, University of Verona, Verona, Italy. ${ }^{4}$ Animal Models and Retroviral Vaccines Section, National Cancer Institute, Bethesda, MD, USA.

Published: 6 June 2011

doi:10.1186/1742-4690-8-S1-A171

Cite this article as: Tosi et al:: The MHC-II transactivator CIITA, a viral restriction factor inhibiting the replication of Human T-Cell Lymphotropic Virus Type 1. Retrovirology 2011 8(Suppl 1):A171.

Submit your next manuscript to BioMed Central and take full advantage of:

- Convenient online submission

- Thorough peer review

- No space constraints or color figure charges

- Immediate publication on acceptance

- Inclusion in PubMed, CAS, Scopus and Google Scholar

- Research which is freely available for redistribution

\section{Biomed Central}

(c) 2011 Tosi et al; licensee BioMed Central Ltd. This is an open access article distributed under the terms of the Creative Commons Attribution License (http://creativecommons.org/licenses/by/2.0), which permits unrestricted use, distribution, and reproduction in any medium, provided the original work is properly cited. 